\title{
China Plates and Japanned Trays: British Encounters with Chinese and Japanese Aesthetics in the Long Nineteenth Century
}

\author{
Waiyee Loh* \\ Department of English and Comparative Literary Studies, University of Warwick \\ *Correspondence: W.Loh@warwick.ac.uk
}

\begin{abstract}
This is a 'Critical Reflection' piece on the research seminar 'China Plates and Japanned Trays: British Encounters with Chinese and Japanese Aesthetics in the Long Nineteenth Century', which was held at the University of Warwick on 20 March 2017. The guest speaker was Dr Jenny Holt (Meiji University). In this seminar, we discussed how the British public responded to the increased availability of Chinese and Japanese art objects in the nineteenth century.
\end{abstract}

Keywords: aesthetics; Britain; China; Japan; nineteenth century

Funding: See page 109

Peer review: This article has been subject to a double blind peer review process

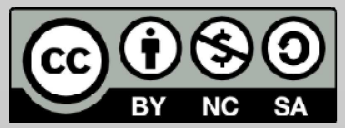

(C) Copyright: The Authors. This article is issued under the terms of the Creative Commons Attribution NonCommercial Share Alike License, which permits use and redistribution of the work provided that the original author and source are credited, the work is not used for commercial purposes and that any derivative works are made available under the same license terms.
In the second half of the nineteenth century, decorative objects from China and Japan became more widely available in Britain, thereby encouraging British consumers to conflate the names of these objects with the names of their countries of origin ('china' for porcelain plate; 'japan' for lacquer ware). How did this increased exposure to Chinese and Japanese art objects - and the distinctive forms of aesthetics that these objects manifested - affect the production of British art and literature in the nineteenth and early twentieth centuries? Can we compare British responses to Chinese art with British responses to Japanese art? How can such comparisons help us understand the ways in which Britain engaged with China and Japan not only as individual countries, but also as part of a regional entity we might call 'East Asia'?

These are some of the big theoretical questions about British attitudes to Chinese and Japanese art objects that 'China Plates and Japanned Trays' attempted to address in a 1.5-hour seminar with Dr Jenny Holt. Jenny Holt is Associate Professor in English Literature at Meiji University, Tokyo. Her research examines Anglophone writing on Japan in the nineteenth and early twentieth centuries, the travel writing of Isabella Bird and Victorian children's literature. At the seminar, we discussed two extracts from Holt's current monograph project, Utopians and Samurai:

Representations of Meiji Period Japan in English Literature, as well as an 
extract from Elizabeth Hope Chang's Britain's Chinese Eye: Literature, Empire, and Aesthetics in Nineteenth-Century Britain (Chang, 2010). The readings were circulated to participants before the seminar.

This article will provide a brief overview of the discussions that occurred during the seminar. Holt began the seminar with a short presentation on the wider theoretical and methodological concerns underpinning the two extracts from her monograph, 'A Lesson to the Western Barbarian:

Culture and Civility in British and American Debates on Japanese Decorative Art during the Meiji Period' and 'Distressed Micropsia: Size Distortion and Psychological Disturbance in Unbeaten Tracks in Japan and Subsequent Travel Literature of the 1880s and 1890s' (Holt, 2017a). Holt observed that Japan does not fit neatly into the Manichean categories of coloniser/colonised and dominant/subordinate, which have dominated critical discussions of Orientalism. Holt showed that, far from belittling Japan as the backward 'Other' of the Western imperial powers, many British and American cultural commentators in the nineteenth and early twentieth centuries held Japan up as an example of a worthy civilisation. These commentators, Holt argued, often saw similarities between British and Japanese society, or they championed Japan as a utopian alternative to the decadence of the West. For the purposes of the seminar, Holt focused on how art enthusiasts such as Rutherford Alcock, who was the British Consul General in Edo (Tokyo) from 1858 1862 and $1864-1865$, and the American art collector James Jackson Jarves, contrasted Japanese aesthetics to what they perceived as the crass and effeminate taste of the British and American middle classes. To these art enthusiasts, the 'Spartan simplicity' of Japanese aesthetics represented the antidote to all the social and aesthetic crises of the fin de siècle: middle-class vulgarity, working-class dissent, mass production and consumption, the feminisation of men, and the decline of Western civilisation.

After Holt's presentation, I gave a ten-minute position paper on Chang's book Britain's Chinese Eye (Chang, 2010). The extract that we had chosen for this seminar was the second chapter on porcelain. In this chapter, Chang claims that the ubiquity of china (porcelain) in Britain in the nineteenth century led to the British public perceiving china as an object that encodes a 'Chinese' way of seeing. The use of non-linear perspective and size distortion in the pictures painted on china function, Chang contends, as a challenge to the British aesthetic tradition of realism. Whereas British artists and writers in the early nineteenth century grappled with this challenge, British artists and writers in the latter half of the nineteenth century turned increasingly to the anti-realist aesthetics of china to create innovative works of art and to distinguish themselves as an artistic avant garde. In my position paper, I discussed 
how Chang's book raised theoretical questions about the particularity of Britain's relationship with China in the nineteenth century. Chang is essentially outlining a 'genealogy' of non-Western aesthetic influence on Euro-American modernism, in which China came before Japan and then Africa as the 'pre-eminent visual and geographical counterpart to EuroAmerican visual and literary modernism' (Chang, 2010: 179). Chang's argument is persuasive, but the distinctions she draws between British engagements with China and with Japan are hard to maintain. At this point, Holt and I encouraged the participants to discuss these issues in the light of the two presentations on British engagements with Japanese and Chinese aesthetics.

We discussed how Chang's 'genealogy' becomes unstable when we consider how Japan, like China, had been exporting art objects (such as lacquer ware) to Europe long before the nineteenth century. Moreover, Britain traded with both China and Japan under the rubric of the treaty port system in the second half of the nineteenth century. As a result, the British public was exposed to both Chinese and Japanese art at the same time. One of the participants noted that Chinese and Japanese merchants also traded art objects with one another, which made it difficult for British merchants to determine the provenance of the art objects they imported. We discussed how this might have contributed to the blurring of distinctions between China and Japan in the Western imagination of 'the Far East', which persists today. One of the participants also brought up the fact that many of these Chinese and Japanese art objects had been made to order for Western markets for centuries, and that their designs had been modified to suit the tastes of Western consumers. This meant that what British and American consumers perceived as 'Chinese' or 'Japanese' aesthetics was in fact a hybrid form. While discussing these complexities, the participants acknowledged that Chang's 'genealogy' has a material historical basis insofar that Britain had established trading and diplomatic relations with China first, while Japan remained closed to most of the Western world until the 1850s. These are the structural reasons why China comes before Japan in Chang's genealogy, even if the circulation of art objects complicates this linear chronology.

In our discussions, we also touched on the paintings of James McNeil Whistler, one of the artists Chang discusses in the extract on porcelain. Whistler's paintings regularly featured both Chinese and Japanese objects (such as blue and white china and Japanese fans and screens) and drew on principles of composition and colour in both china and Japanese ukiyo-e woodblock prints. The striking similarity between Holt's description of British, and more broadly Western, attitudes towards Japanese art and Chang's account of British perceptions of Chinese art raises the prospect of comparing these responses. The participants noted 
that both Holt and Chang emphasise the impact that the use of nonlinear perspective and size distortion had on British art in the nineteenth and early twentieth centuries. Holt clarified that this British fascination with perspective in Japanese art was limited to the reception of woodblock prints, and was not extended to other kinds of Japanese decorative art such as ceramics, which were valued instead for their 'Spartan simplicity'. The discussion raised the possibility that Chang's notion of antithesis and her category of the 'anti-realist' are too broad to be useful in identifying the specificities of cultural relations between Britain and China, or between Britain and Japan. As one of the participants noted, the categories we use to describe cross-cultural interactions are often inadequate in capturing the nuances of these interactions.

We look forward to continuing these discussions at the $2018 \mathrm{MLA}$ Convention in New York City, where Holt and I will be participating in the Working Group on 'Literature, Aesthetics, and Cultural Exchange between East Asia and Southeast Asia and Britain and North America in the Long Nineteenth Century.'

\section{Acknowledgements}

The event was kindly sponsored by the Institute of Advanced Study, University of Warwick. 


\section{References}

Chang, E. (2010), Britain's Chinese Eye: Literature, Empire, and Aesthetics in Nineteenth-Century Britain, Stanford: Stanford University Press

Holt, J. (2017), 'Distressed Micropsia: Size Distortion and Psychological Disturbance in Unbeaten Tracks in Japan and Subsequent Travel Literature of the 1880s and 1890s', China Plates and Japanned Trays: British Encounters with Chinese and Japanese Aesthetics in the Long Nineteenth Century research seminar, University of Warwick, Coventry, 20 March 2017

Holt, J. (2017), 'A Lesson to the Western Barbarian: Culture and Civility in British and American Debates on Japanese Decorative Art during the Meiji Period', China Plates and Japanned Trays: British Encounters with Chinese and Japanese Aesthetics in the Long Nineteenth Century research seminar, University of Warwick, Coventry, 20 March 2017

To cite this article:

Loh, W. (2017). China Plates and Japanned Trays: British Encounters with Chinese and Japanese Aesthetics in the Long Nineteenth Century. Exchanges: the Warwick Research Journal, 5(1), 106-110. Retrieved from: http://exchanges.warwick.ac.uk/index.php/exchanges/article/view/202 